Atmos. Chem. Phys., 10, 2007-2015, 2010

www.atmos-chem-phys.net/10/2007/2010/

(C) Author(s) 2010. This work is distributed under

the Creative Commons Attribution 3.0 License.

\title{
A numerical evaluation of global oceanic emissions of $\alpha$-pinene and isoprene
}

\author{
G. Luo and F. Yu \\ Atmospheric Sciences Research Center, State University of New York, 251 Fuller Road, Albany, New York, 12203, USA
}

Received: 25 August 2009 - Published in Atmos. Chem. Phys. Discuss.: 1 October 2009

Revised: 4 February 2010 - Accepted: 9 February 2010 - Published: 19 February 2010

\begin{abstract}
A numerical evaluation of global oceanic emissions of $\alpha$-pinene and isoprene based on both "bottom-up" and "top-down" methods is presented. We infer that the global "bottom-up" oceanic emissions of $\alpha$-pinene and isoprene are $0.013 \mathrm{TgC} \mathrm{yr}^{-1}$ and $0.32 \mathrm{TgC} \mathrm{yr}^{-1}$, respectively. By constraining global chemistry model simulations with the shipborne measurement of Organics over the Ocean Modifying Particles in both Hemispheres summer cruise, we derived the global "top-down" oceanic $\alpha$-pinene source of $29.5 \mathrm{TgC} \mathrm{yr}^{-1}$ and isoprene source of $11.6 \mathrm{TgC} \mathrm{yr}^{-1}$. Both the "bottom-up" and "top-down" values are subject to large uncertainties. The incomplete understanding of the in-situ phytoplankton communities and their range of emission potentials significantly impact the estimated global "bottomup" oceanic emissions, while the estimated total amounts of the global "top-down" oceanic sources can be influenced by emission parameterizations, model and input data spatial resolutions, boundary layer mixing processes, and the treatments of chemical reactions. The global oceanic $\alpha$-pinene source and its impact on organic aerosol formation is significant based on "top-down" method, but is negligible based on "bottom-up" approach. Our research highlights the importance of carrying out further research (especially measurements) to resolve the large offset in the derived oceanic organic emission based on two different approaches.
\end{abstract}

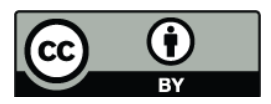

Correspondence to: G. Luo

(ganluo@asrc.cestm.albany.edu)

\section{Introduction}

Satellite remote sensing has indicated high aerosol optical depth over the Southern Ocean (Kaufman et al., 2002). Because of the potential impact of these aerosols on the Antarctic and Southern Ocean multidecadal climate changes via direct and indirect radiative forcing (Mayewski et al., 2009), the chemical composition and formation mechanism of aerosols over this region has been one of the most intriguing questions in atmospheric chemistry and climate studies. Sea salt, dimethylsulfide (DMS), and primary and secondary organic carbon have all been suggested as species that may have significant contribution to the aerosol zone over the Southern Ocean (Ceburnis et al., 2008; Gabric et al., 2005; Meskhidze and Nenes, 2006; Murphy et al., 1998; O’Dowd et al., 2008).

Global modeling has indicated the presence of missing large organic aerosol sources in the troposphere (Gantt et al., 2009; Heald et al., 2005, 2006; Roelofs, 2008; Spracklen et al., 2008), although the exact species and sources remain controversial. Heald et al. (2006) introduced in GEOS-Chem a $27 \mathrm{TgC} \mathrm{yr}^{-1}$ marine OC aerosol source by convolving the sea salt aerosol source with the seasonal variation of marine primary productivity, and scaling globally this source to match mean OC aerosol measurements over the remote oceans. Spracklen et al. (2008) derived an empirical relation between SeaWiFS chlorophylla concentration and the oceanic OC emission flux, and showed that $8 \mathrm{TgC} \mathrm{yr}^{-1}$ of global oceanic OC emissions (primary plus secondary) are needed to match the OC aerosol concentrations observed at three oceanic surface sites. Roelofs (2008) estimated that globally, about $75 \mathrm{TgC} \mathrm{yr}^{-1}$ of organic matter from marine origin enters the aerosol

Published by Copernicus Publications on behalf of the European Geosciences Union. 
phase, with comparable contributions from primary emissions $\left(\sim 35-50 \mathrm{TgC} \mathrm{yr}^{-1}\right)$ and secondary organic aerosol formation $\left(\sim 25-40 \mathrm{TgC} \mathrm{yr}^{-1}\right)$. Isoprene was suggested as the most probable source for the marine secondary organic aerosol (SOA) (Meskhidze and Nenes, 2006; Roelofs, 2008). However, in-situ observation, satellite measurements and model simulation inferred that the total annual mean oceanic isoprene emission is only $\sim 0.1-1.9 \mathrm{Tg} \mathrm{yr}^{-1}$ (Arnold et al., 2009; Broadgate et al., 1997; Gantt et al., 2009; Palmer and Shaw, 2005), too low to explain the water soluble organic carbon (WSOC) observed over the ocean.

Recent shipborne measurement of Organics over the Ocean Modifying Particles in both Hemispheres (OOMPH) summer cruise reported that both marine $\alpha$-pinene and isoprene, along their route from Cape Town of South Africa to Punta Arenas of Chile, can reach up to $\sim 150$ pptv over an active phytoplankton bloom (Yassaa et al., 2008). The data was obtained by analyzing the cartridges from shipborne samples using a gas chromatograph-mass spectrometer (GC-MS) analysis system, with the detection limits of isoprene and $\alpha$ pinene ranging from 1 to $5 \mathrm{pptv}$, and the total uncertainties of $\sim 10-15 \%$ (Yassaa et al., 2008). Yassaa et al. (2008) also incubated several phytoplankton cultures and measured their monoterpene emission rates in the laboratory. The shipborne measurements and laboratory incubation experiments of Yassaa et al. (2008) provided the first evidence of marine production of $\alpha$-pinene. Compared to isoprene, $\alpha$-pinene has much higher reactivity and SOA yield. A substantial concentration of $\alpha$-pinene over the ocean is a strong indication of significant oceanic source. As far as we know, the global evaluation of oceanic $\alpha$-pinene emission has not been studied before.

The main objective of this study is to derive the global oceanic $\alpha$-pinene source strength based on both "bottom-up" and "top-down" methods. For comparison, oceanic isoprene emission is also derived in a similar way. The uncertainties which may impact the evaluation of global "bottom-up" and "top-down" oceanic emissions of $\alpha$-pinene and isoprene are discussed. And we also investigate the possible impact of these oceanic emissions on SOA formation and chemistry over the Southern Ocean.

\section{Treatment of oceanic organic emissions}

Previous studies indicated a correlation between the seasonal cycle of OC measured at surface sites and oceanic chlorophyll-a concentration ([Chl-a]) observed from satellite. Two different methods have been widely used to estimate oceanic OC emissions: one is the "bottom-up" method which deduces the sea-to-air emissions based on the emission flux measurements (Arnold et al., 2009; Gantt et al., 2009); the other is "top-down" method which infers the key parameters via matching final simulations with observations (Arnold et al., 2009; Heald et al., 2006; Spracklen et al., 2008). Spracklen et al. (2008) obtained the oceanic
OC emission through scaling [Chl-a] by an emission factor $A=3.2 \mathrm{ngC} \mathrm{m}^{-2} \mathrm{~s}^{-1} / \mathrm{mg}$ [Chl-a] m${ }^{-3}$. Arnold et al. (2009) inferred a mean "bottom-up" oceanic isoprene emission of $0.31 \pm 0.08 \mathrm{Tg} \mathrm{yr}^{-1}$, and a "top-down" oceanic isoprene source estimate of $1.9 \mathrm{Tg} \mathrm{yr}^{-1}$. Gantt et al. (2009) developed a new physically-based parameterization for the emission of isoprene and primary organic matter that takes into account the effect of [Chl-a], solar radiation, total water depth, and wind speed on emission.

In this study, we calculated the "bottom-up" emission flux $\left(F_{\mathrm{VOC}}, \mathrm{VOC}=\alpha\right.$-pinene, isoprene $)$ as Arnold et al. (2009),

$F_{\mathrm{VOC}}=R_{\mathrm{VOC}}[\mathrm{Chl}-\mathrm{a}] D_{\mathrm{ML}}$

where $R_{\mathrm{VOC}}$ is the emission rate of VOC (Arnold et al., 2009; Yassaa et al., 2008), which is determined by the measurements and experiments for the phytoplankton classes considered by the PHYSAT model (Alvain et al., 2008). [Chla] is the monthly mean oceanic chlorophyll-a concentration at model resolution which is regrided from the merged MODIS Aqua and SeaWiFS chlorophyll-a Level-3 products with $9 \mathrm{~km} \times 9 \mathrm{~km}$ resolution, and $D_{\mathrm{ML}}$ is the climatic monthly mean mixed layer depth (de Boyer et al., 2004).

Based on the "top-down" method, we calculate oceanic emission of $\alpha$-pinene and isoprene with the following formula, which parameterizes emission flux $\left(F_{\mathrm{VOC}}, \mathrm{VOC}=\alpha\right.$ pinene, isoprene) as a function of [Chl-a], $D_{\mathrm{ML}}, R_{\mathrm{VOC}}$, effective solar radiation rate $\left(R_{\text {sun }}\right)$, surface wind velocity at 1 $\mathrm{m}\left(W_{10 \mathrm{~m}}\right)$, and Schmidt number $(S c)$.

$$
\begin{aligned}
& F_{\mathrm{VOC}}\left(\text { in } \mathrm{kg} \mathrm{m}^{-2} \mathrm{~s}^{-1}\right)=\xi_{\mathrm{VOC}}[\mathrm{Chl}-\mathrm{a}] \\
& D_{\mathrm{ML}} R_{\mathrm{VOC}} R_{\text {sun }} k_{600} \sqrt{S \mathrm{COO}_{2} / S c \mathrm{VOC}}
\end{aligned}
$$

where $\xi_{\mathrm{VOC}}$ is a prefactor that is to be determined by matching modeled VOC concentrations with those measured (the details of how to obtain the prefactor are described in supplementary material: http://www.atmos-chem-phys.net/ 10/2007/2010/acp-10-2007-2010-supplement.pdf). $R_{\text {sun }}$ depends on solar altitude, optical depth of cloud and aerosol, and surface albedo. The exact simulation of $R_{\text {sun }}$ needs a full radiative transfer model. In this study, we only consider the spatial and temporal impact of solar altitude. $k_{600}$ is the gas transfer velocity normalized to a Schmidt number $(S c)$ of 600 which is calculated based on the fitted formula of Nightingale et al. (2000),

$k_{600}=0.24 W_{10 \mathrm{~m}}^{2}+0.061 W_{10 \mathrm{~m}}$

where $W_{10 \mathrm{~m}}$ is the surface wind speed extracted from GEOS5 metrological field. The Schmidt number, $S c$, is defined as the kinematic viscosity of water divided by diffusion coefficient of the gas. In the present study, $S \mathrm{C}_{\mathrm{CO}_{2}}=600$, while $S c_{\text {VOC }}$ is calculated via the third-order polynomial fit of sea surface temperature (SST) (Palmer and Shaw, 2005; Wanninkhof, 1992). 

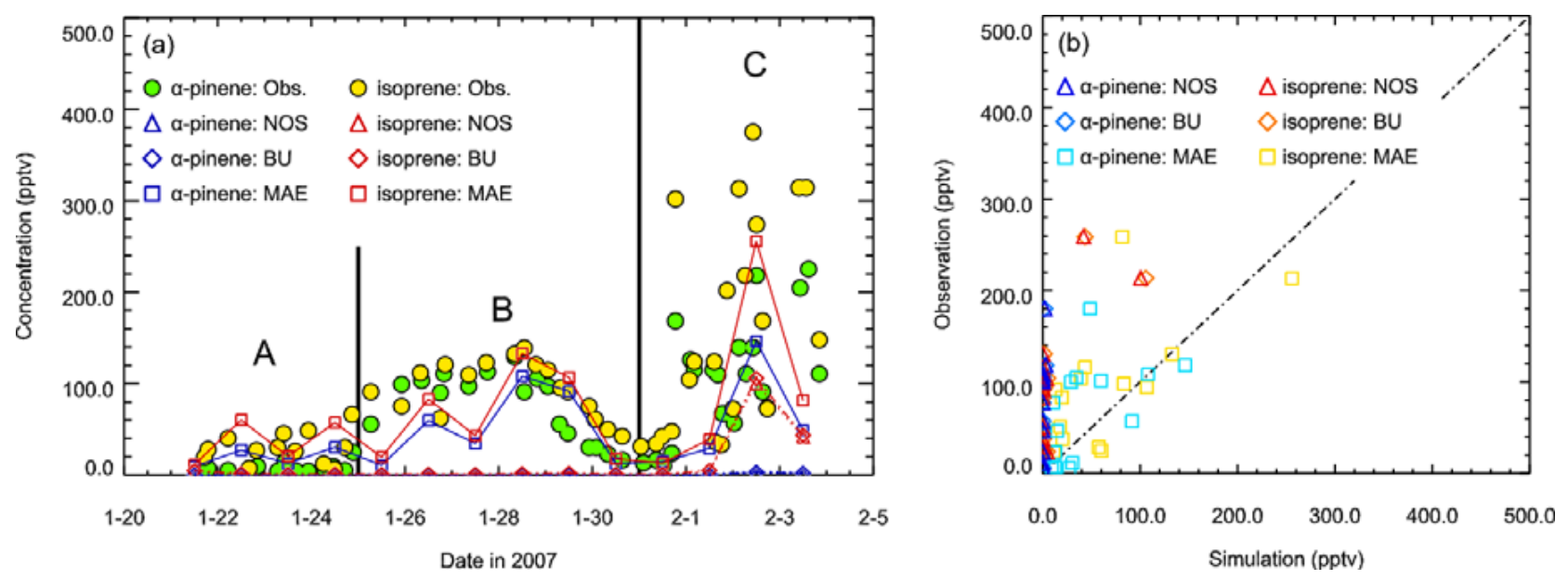

Fig. 1. (a) A comparison of observed and simulated $\alpha$-pinene and isoprene concentrations along the route of shipborne measurement (1/22/2007-2/4/2007) during the OOMPH summer cruise reported in Yassaa et al. (2008). (b) A scatter diagram of observed versus simulated $\alpha$-pinene and isoprene concentrations. Obs: the OOMPH measurements; NOS: no oceanic organic emissions; BU: "bottomup" emissions; MAE: "top-down" MAE prefactor emissions. Definitions of MAE prefactors are given in supplementary material: http://www.atmos-chem-phys.net/10/2007/2010/acp-10-2007-2010-supplement.pdf.

\section{Oceanic $\alpha$-pinene and isoprene emissions and the associated impact on SOA concentrations}

The global model employed in this study is GEOS-Chem v802-02 (http://acmg.seas.harvard.edu/geos), with an advanced particle microphysics model (APM) incorporated to treat size-resolved microphysics, dry deposition, and wet scavenging for aerosols (for details, see Yu and Luo, 2009). The updated GEOS-Chem is driven by the assimilated meteorological data from the NASA Goddard Earth Observing System 5 (GEOS-5) at $4^{\circ} \times 5^{\circ}$ horizontal resolutions. With GEOS-Chem and Eq. (1), we find that the global "bottom-up" oceanic emission of $\alpha$-pinene and isoprene in the year 2006 are $0.013 \mathrm{TgC} \mathrm{yr}^{-1}$ and $0.32 \mathrm{TgC} \mathrm{yr}^{-1}$, respectively. Our calculated value of global oceanic isoprene emission is close to that of Arnold et al. (2009) $\left(0.31 \mathrm{Tg} \mathrm{yr}^{-1}\right.$ for year 2000), based on the similar approach. Because of the much lower emission rates $\left(R_{\mathrm{VOC}}\right)$ of $\alpha$-pinene based on laboratory measurements (see Table S1 in supplementary material: http://www.atmos-chem-phys.net/10/ 2007/2010/acp-10-2007-2010-supplement.pdf), the global "bottom-up" oceanic emission of $\alpha$-pinene is a factor of $\sim 25$ smaller than that of isoprene.

Due to their high reactivity and thus short lifetime, the concentrations of $\alpha$-pinene and isoprene over the oceans are generally negligible $(<1 \mathrm{pptv})$ in the absence of oceanic source. The observed high concentrations (up to $\sim 150 \mathrm{pptv}$ ) of $\alpha$-pinene and isoprene over the Southern Ocean, as reported by Yassaa et al. (2008), strongly suggest an oceanic source of these species. One logical question to ask is: can the "bottom-up" emission fluxes calculated above account for the observed $\alpha$-pinene and isoprene over the Southern
Ocean? If not, what is the amount of the emission needed to maintain the observed concentrations (i.e., "top-down" emission values)? To answer these questions, we employ GEOS-Chem, which includes online organic chemistry (the chemical reactions for $\alpha$-pinene/monoterpene and isoprene oxidations in GEOS-Chem are shown in supplementary material: http://www.atmos-chem-phys.net/10/2007/2010/ acp-10-2007-2010-supplement.pdf) and takes into account transport and deposition processes.

Figure 1a shows a comparison of simulated $\alpha$-pinene and isoprene concentrations for different emission scenarios with those measured along the ship route reported in Yassaa et al. (2008). A scatter diagram of observed and simulated daily mean $\alpha$-pinene and isoprene concentrations during the same period is shown in Fig. 1b. The mean error (ME), normalized mean error (NME), and mean absolute error (MAE) of the simulated $\alpha$-pinene and isoprene concentrations, with respect to the observed values, are summarized in Table 1. Yassaa et al. (2008) divided the observations into 3 regions: the low chlorophyll-a regions (region A) from $20^{\circ} 22^{\prime} \mathrm{E}, 35^{\circ} 49^{\prime} \mathrm{S}$ to $11^{\circ} 17^{\prime} \mathrm{W}, 43^{\circ} 18^{\prime} \mathrm{S}$; the distant bloom area (region $\mathrm{B}$ ) from $11^{\circ} 17^{\prime} \mathrm{W}, 43^{\circ} 18^{\prime} \mathrm{S}$ to $48^{\circ} 42^{\prime} \mathrm{W}, 41^{\circ} 51^{\prime} \mathrm{S}$; and the insitu bloom region (region $\mathrm{C}$ ) from $48^{\circ} 42^{\prime} \mathrm{W}, 41^{\circ} 51^{\prime} \mathrm{S}$ to $65^{\circ} 47^{\prime} \mathrm{W}, 47^{\circ} 54^{\prime} \mathrm{S}$. It is clear that the model without oceanic organic emissions (NOS) cannot reproduce the value of the shipborne measurements, especially over remote ocean regions. The "bottom-up" emissions (BU) does not present noticeable changes in $\alpha$-pinene concentrations, while the daily average isoprene concentration enhances by $\sim 1-5 \mathrm{pptv}$, still much lower than the observed values. With BU emissions, the mean error, normalized mean error, and mean absolute error of $\alpha$-pinene and isoprene are in the ranges of $60-90 \mathrm{pptv}$, 
Table 1. The mean error (ME), normalized mean error (NME), and mean absolute error (MAE) of $\alpha$-pinene and isoprene concentrations for three different emission scenarios.

\begin{tabular}{lcccccc}
\hline & ME: & $\begin{array}{c}\text { ME: } \\
\alpha \text {-pinene }\end{array}$ & $\begin{array}{c}\text { NME: } \\
\text { isoprene }\end{array}$ & $\begin{array}{c}\text { NME: } \\
\alpha \text {-pinene }\end{array}$ & $\begin{array}{c}\text { MAE: } \\
\text { isoprene }\end{array}$ & MAE: \\
\hline NSO & -67.2 & -86.1 & $-99.4 \%$ & $-88.9 \%$ & 67.2 & 86.1 \\
BU & -67.2 & -84.7 & $-99.3 \%$ & $-87.5 \%$ & 67.2 & 84.7 \\
MAE & -22.2 & -29.5 & $-32.9 \%$ & $-30.5 \%$ & 38.3 & 46.9 \\
\hline
\end{tabular}

$80-100 \%$ and $60-90$ pptv, respectively (Table 1 ). The detailed source and sink information for $\alpha$-pinene and isoprene based on the "bottom-up" and "top-down" approaches on three selected days in regions $\mathrm{A}, \mathrm{B}$, and $\mathrm{C}$ are discussed in the supplement material: http://www.atmos-chem-phys.net/ 10/2007/2010/acp-10-2007-2010-supplement.pdf.

To account for the observed $\alpha$-pinene and isoprene concentrations along the ship route, we calculated the emission rates based on Eq. (2) and determined the prefactors by minimizing the MAE of simulated values (see supplementary material for details: http://www.atmos-chem-phys.net/ 10/2007/2010/acp-10-2007-2010-supplement.pdf). By using "top-down" MAE prefactor emissions, all of ME, NME and MAE have been significantly reduced. In MAE prefactor case, the ME of $\alpha$-pinene and isoprene are only $-22.2 \mathrm{pptv}$ and $-29.5 \mathrm{pptv}$, respectively; while the NME of $\alpha$-pinene and isoprene are reduced to $-32.91 \%$ and $-30.5 \%$, respectively. The MAE of $\alpha$-pinene and isoprene are $38.3 \mathrm{pptv}$ and 46.9 pptv, respectively. As discussed by Yassaa et al. (2008) and shown in the scattering of the data points given in Fig. 1a, the minimum and maximum of the observed isoprene and $\alpha$-pinene concentrations in different regions are generally within a factor of 2-5 of the averaged values. Both the concentrations and driving factors could vary substantially on the $4^{\circ} \times 5^{\circ}$ model grid scale used here. Our present modeling studies aim to derive average emissions over a grid box, and it is clear from Table 1 and Fig. 1 that there exist differences between simulated and observed values.

The comparisons between GEOS-Chem simulations and the OOMPH measurements indicate that the "bottom-up" oceanic emission can hardly explain the observed $\alpha$-pinene and isoprene along the ship route (isoprene is also observed by previous measurements e.g., Yokouchi et al., 1999). In contrast, with the "top-down" oceanic organic emissions, model simulations are able to capture the major trend of the shipborne measurement along the route.

To assess the global source of oceanic organics and the associated impact on SOA abundance, we carried out three case studies: one without oceanic organic emissions (NOS), the second considering the "bottom-up" oceanic $\alpha$-pinene and isoprene emissions, and the third considering the "top-down" oceanic $\alpha$-pinene and isoprene emissions (based on Eq. 2 with MAE prefactors $\xi_{\alpha-\text { pinene }}=1.4 \times 10^{3}$ and $\xi_{\text {isoprene }}=17.0$ ).
The MAE prefactors are used because they provide simulated results closest to the OOMPH measurements. Figure 2 shows the horizontal distributions of annual mean concentrations (for the year 2006) of $\alpha$-pinene and isoprene in the surface layer for the three cases. The global terrestrial emission of $\alpha$-pinene and isoprene used in GEOS-Chem v8-02-02 for the year 2006 are $105 \mathrm{TgC} \mathrm{yr}^{-1}$ and $572 \mathrm{TgC} \mathrm{yr}^{-1}$, respectively. However, because of their short atmospheric lifetime, the high surface concentrations of $\alpha$-pinene and isoprene, which can reach up to $300 \mathrm{pptv}$ and $2000 \mathrm{pptv}$, are mainly confined to land. Without oceanic emissions, the surface concentrations of $\alpha$-pinene and isoprene over most oceans are near 0 (Fig. 2a and b). It is clear that the transport from terrestrial sources cannot account for the abundance of $\alpha$-pinene and isoprene observed in the remote marine boundary layer as reported in Yassaa et al. (2008). When we employed the "bottom-up" emissions in GEOS-Chem, the concentration of $\alpha$-pinene in surface layer shows negligible changes, while the concentration of isoprene at remote oceans is enhanced by $\sim 10$ pptv. When oceanic emissions with source strengths that give reasonable agreement with shipborne measurement are considered (Fig. 1), the annual mean surface concentrations of $\alpha$-pinene and isoprene over the oceans are substantially enhanced, especially in middle latitude marine regions. As a result of large emissions associated with high chlorophyll-a concentrations and wind speeds, $\alpha$-pinene and isoprene concentrations in the Southern Ocean regions $\left(40^{\circ} \mathrm{S}-60^{\circ} \mathrm{S}\right)$ are significantly enhanced and can reach up to $100 \mathrm{pptv}$.

Based on Eq. (2) and MAE prefactors, the global "top-down" oceanic emissions of $\alpha$-pinene and isoprene are $29.5 \mathrm{TgC} \mathrm{yr}^{-1}$ and $11.6 \mathrm{TgC} \mathrm{yr}^{-1}$, respectively. The $29.5{\mathrm{TgC} \mathrm{yr}^{-1}}^{-1}$ "top-down" oceanic $\alpha$-pinene emission derived in this study, which is about a quarter of the total terrestrial sources $\left(105 \mathrm{TgC} \mathrm{yr}^{-1}\right)$, is significant compared with the terrestrial source. Figure $2 \mathrm{c}$ indicates that $\alpha$-pinene concentration over the Southern Ocean is comparable to the values over North America, Europe, and East Asia. The 11.6 $\mathrm{TgC}^{-1}$ "top-down" oceanic isoprene emission derived in this study by constraining the model simulations with Yassaa et al. (2008)'s shipborne measurement is higher than the Arnold et al. (2009)'s "top-down" estimation of $1.9 \mathrm{Tg} \mathrm{yr}^{-1}$, which was derived from a different set of isoprene observations over remote oceans.

Apparently, there exists a huge difference in the derived $\alpha$-pinene and isoprene emissions from "bottom-up" and "top-down" methods. The offset for $\alpha$-pinene (a factor of $\sim 2300$ ) is much larger than that for isoprene (a factor of 36). Arnold et al. (2009) showed that oceanic isoprene emission derived from "top-down" method is a factor of $\sim 6$ higher than that based on "bottom-up" calculation. Our study, based on a different set of isoprene measurements over remote oceans, confirms the existence of such offset for isoprene. The much larger offset for $\alpha$-pinene is associated with the much lower $\alpha$-pinene 
(a) a-pinene: NOS, Sfc, 2006 (pptv)

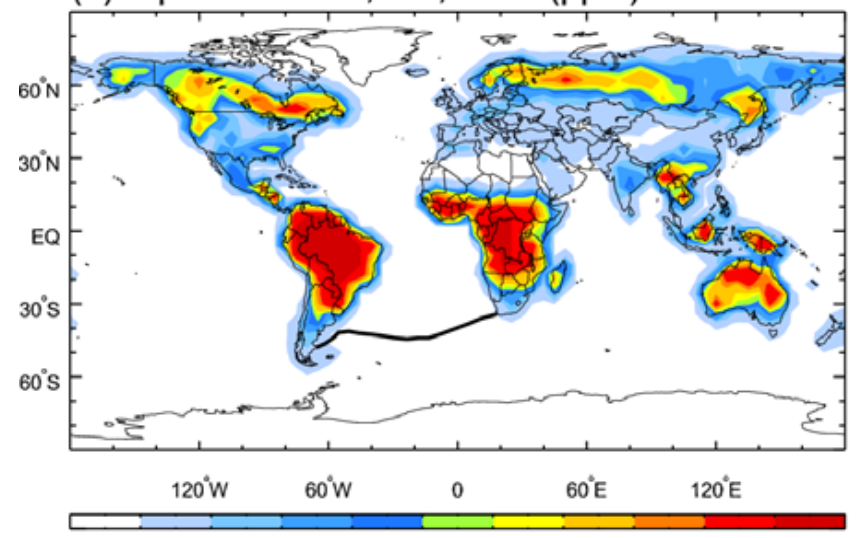

$\begin{array}{llllllllll}1 & 10 & 20 & 40 & 60 & 80 & 100 & 150 & 200 & 300\end{array}$

(c) a-pinene: BU, Sfc, 2006 (pptv)

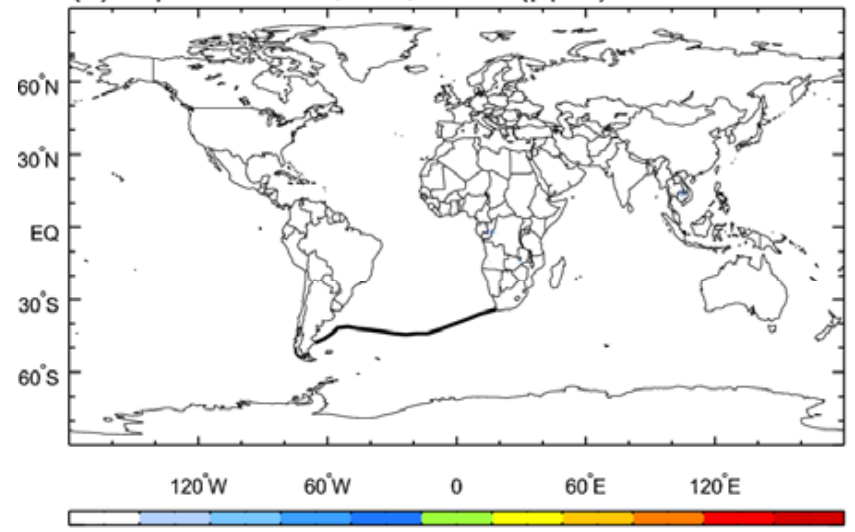

$\begin{array}{llllllllll}1 & 10 & 20 & 30 & 40 & 60 & 80 & 100 & 120 & 150\end{array}$

(e) a-pinene: MAE, Sfc, 2006 (pptv)

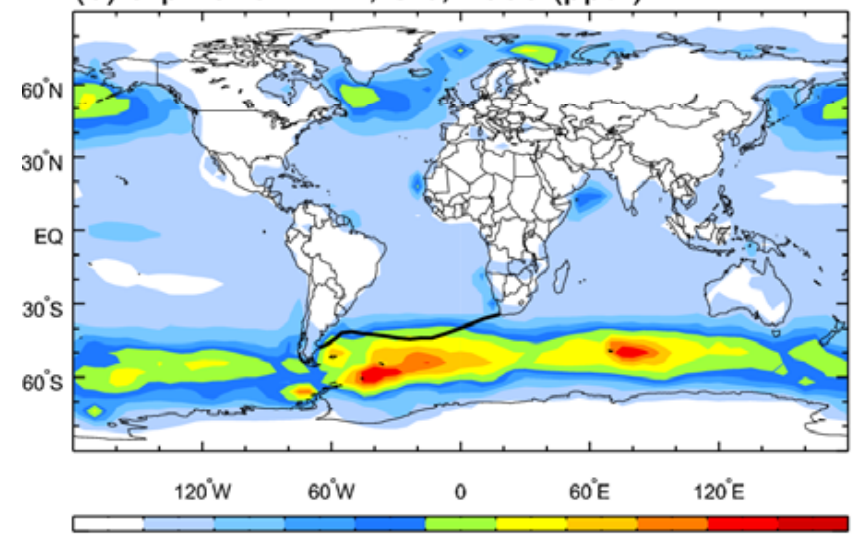

$\begin{array}{llllllllll}1 & 10 & 20 & 30 & 40 & 60 & 80 & 100 & 120 & 150\end{array}$ (b) isoprene: NOS, Sfc, 2006 (pptv)

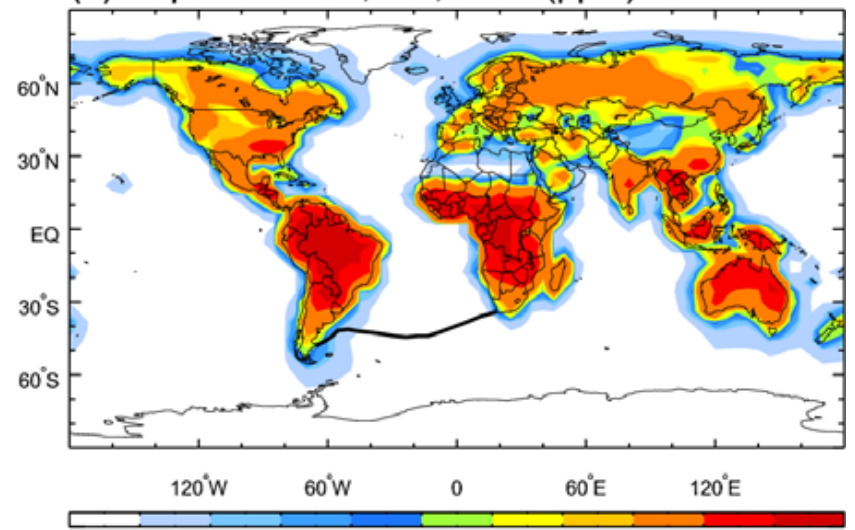

$1 \quad 10 \quad 20 \quad 40 \quad 60 \quad 100 \quad 150 \quad 200 \quad 10002000$

(d) isoprene: $\mathrm{BU}, \mathrm{Sfc}, 2006$ (pptv)

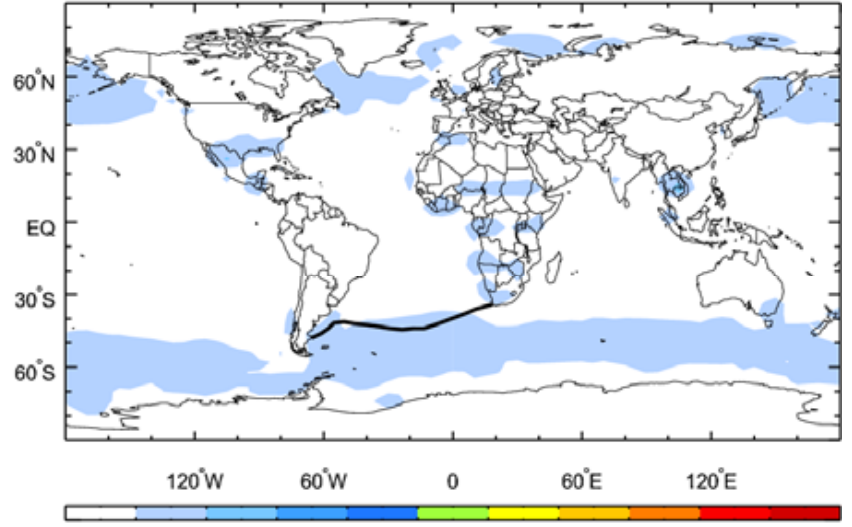

$\begin{array}{llllllllll}1 & 10 & 20 & 30 & 40 & 60 & 80 & 100 & 120 & 150\end{array}$

(f) isoprene: MAE, Sfc, 2006 (pptv)

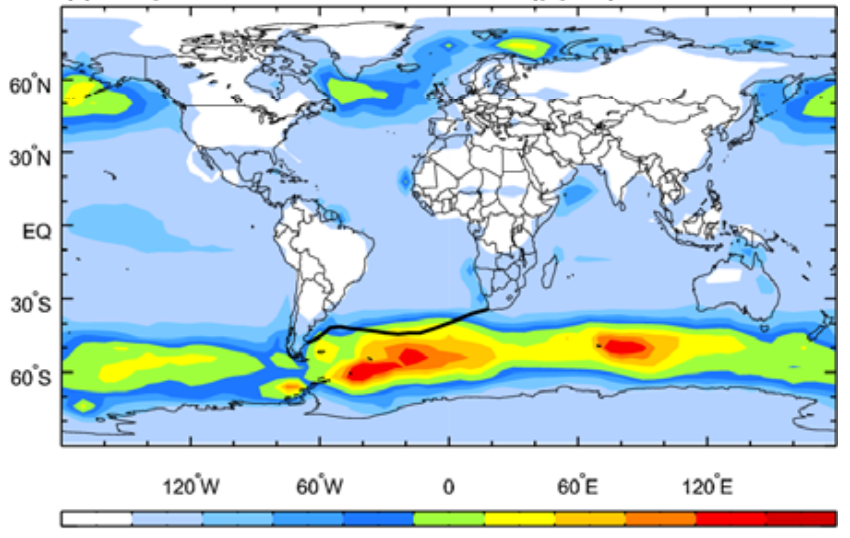

$\begin{array}{llllllllll}1 & 10 & 20 & 30 & 40 & 60 & 80 & 100 & 120 & 150\end{array}$

Fig. 2. Annual mean concentrations of $\alpha$-pinene and isoprene at surface layer: (a) $\alpha$-pinene without oceanic emission (NOS); (b) isoprene without oceanic emission (NOS). Annual mean differences of $\alpha$-pinene and isoprene at surface layer: (c) the difference of $\alpha$-pinene between the "bottom-up" (BU) case and the NOS case; (d) the difference of isoprene between the BU and the NOS; (e) the difference of $\alpha$-pinene between the "top-down" MAE prefactor case and the NOS case; (f) the difference of isoprene between the MAE case and the NOS case. 
emission potentials of major phytoplankton types based on laboratory flux measurements (Table S1, supplementary material: http://www.atmos-chem-phys.net/10/2007/2010/ acp-10-2007-2010-supplement.pdf). As discussed in Arnold et al. (2009), the possible reasons for the offset include incomplete understanding of the in-situ phytoplankton communities and their range of emission potentials as well as the uncertainties in the "top-down" approach..

The offset by a factor of 2300 in the derived oceanic $\alpha$ pinene emissions from "bottom-up" and "top-down" methods is obviously significant. However, it is difficult to determine which emission source is more realistic, and further research (especially in-situ measurements) is needed to resolve the differences. As we have shown in Fig. 1, there is no way that the "bottom-up" oceanic emission can explain the observed $\alpha$-pinene and isoprene along the ship route. As mentioned earlier, both the concentrations and driving factors could vary substantially on the $4^{\circ} \times 5^{\circ}$ model grid scale used in the present study. In addition, the limited vertical resolution of the model could also lead to uncertainty. During OOMPH measurements VOC concentrations were collected at $18 \mathrm{~m}$ above sea level (Yassaa et al., 2008). The usage of first model layer $(0-130 \mathrm{~m})$ to represent the mean surface concentrations in comparison with ship data may overestimate the required oceanic fluxes and therefore lead to excessive "top-down" global emissions estimates. As shown in the work of Guenther et al. (1996), the observed isoprene concentration at $\sim 20 \mathrm{~m}$ is $\sim 2-3$ times higher than that at $\sim 0-125 \mathrm{~m}$. The decay of VOC mixing ratios reported in Guenther et al. (1996) was observed over forests and similar observation is not available over remote marine regions. If we assume the decay of VOC mixing ratios with altitudes as suggested by Guenther et al. (1996) in the model grid, the estimated total amounts of the global "top-down" oceanic $\alpha$-pinene and isoprene sources could reduce to $\sim 10$ $15 \mathrm{TgC} \mathrm{yr}^{-1}$ and $\sim 4-6 \mathrm{TgC} \mathrm{yr}^{-1}$, respectively. It is clear that further modeling studies with higher spatial and temporal resolutions and improved emission schemes are needed to reduce the uncertainty in the estimations of oceanic emissions.

It should be emphasized that the $\alpha$-pinene concentration data, which the current study relied on, is spatially and temporally limited. As far as we know, no other remote marine monoterpene observations exist, except those reported in Yassaa et al. (2008). Nevertheless, we would also like to point out that OOMPH measurements covered a reasonably wide area in the southern ocean region (from Cape Town, South Africa to Punta Arenas, Chile), and the measurements were taken during a period of more than two weeks coinciding with the annual phytoplankton maximum in the region. As shown in Figure 2, around 50\% of annual oceanic $\alpha$-pinene emission (i.e., $\sim 30 \mathrm{TgC} / \mathrm{yr}$ ) is from the southern ocean region $\left(\sim 30^{\circ} \mathrm{S}-75^{\circ} \mathrm{S}\right)$ during the phytoplankton active season (also see Fig. S2 in the supplementary material: http://www.atmos-chem-phys.net/10/ 2007/2010/acp-10-2007-2010-supplement.pdf). Thus, we feel that OOMPH measurement of oceanic $\alpha$-pinene could be reasonably representative, although additional measurements of $\alpha$-pinene over remote oceans are clearly needed.

$\alpha$-pinene is well recognized to be an important precursor of SOA. The SOA yielding from $\alpha$-pinene photo-oxidation products is much higher than that of isoprene. Experimental studies estimate that the SOA yield from $\alpha$-pinene (32\%) is 16 times higher than that of isoprene (2\%) (Lee et al., 2006). The potential importance of oceanic $\alpha$-pinene emission can be assessed with GEOS-Chem, which includes the up-todate schemes of the organic chemistry (Liao et al., 2007). In GEOS-Chem, the summary of secondary organic gas (SOG) and SOA represents the total semi-volatile reactions productions of VOCs with $\mathrm{OH}, \mathrm{O}_{3}$ and $\mathrm{NO}_{3}$ (Chung et al., 2002). Due to the current uncertainty in the scheme to partition the semi-volatile reactions productions into gas phase (SOG) and aerosol phase (SOA), we include SOG in our discussion in order to show the impacts of $\alpha$-pinene and isoprene on total condensable secondary organic matters (SOG1 and SOA1 represent the secondary organic gas and aerosol produced from $\alpha$-pinene and $\beta$-pinene group, while SOG4 and SOA4 represent the secondary organic gas and aerosol produced from isoprene group) in the marine boundary layer over the Southern Ocean. Figure 3 presents the zonallyaveraged relative and absolute differences in SOG1+SOA1 and SOG4+SOA4 between the MAE case (with "top-down" emissions) and the NOS case (no oceanic emissions) during the summer season (DJF) in the Southern Hemisphere. The zonally-averaged SOG1+SOA1 enhanced by more than $100 \mathrm{ngC} \mathrm{m}^{-3}$ within the latitude range of $\sim 40^{\circ} \mathrm{S}-60^{\circ} \mathrm{S}$ (Fig. 3b), with the corresponding relative change in the boundary layer reaches above $200 \%$ (Fig. 3a). The enhancement of SOG4+SOA4 is about $9 \mathrm{ngC} \mathrm{m}^{-3}$ (Fig. 3d), and its relative change is $\sim 10-50 \%$ (Fig. 3c). Arnold et al. (2009) suggested that the contribution of isoprene to total OC measured at 3 remote sites is $\sim 1 \%$. Our research also indicates that isoprene has a small contribution to the formation of SOA. Our simulations indicate that $\alpha$-pinene from oceans, which is derived from the "top-down" method, may significantly contribute to the formations of SOA over the Southern Ocean during the summer season. The secondary organics, which are produced from $\alpha$-pinene, may partially explain the observed seasonal variations of organic mass and the soluble fraction over coast and remote oceans (Ceburnis et al., 2008; Spracklen et al., 2008).

\section{Summary and discussion}

In-situ measurements indicate significant amounts of organic carbon aerosols within the marine boundary layer, especially in the regions with enhanced oceanic biological activity. A substantial fraction of these organic carbon aerosols are water soluble (WSOC), but the source of these WSOC remains to be established. The present study mainly focuses on the 
(a) 2006 DJF Zonal SOG1+SOA1 (\%)

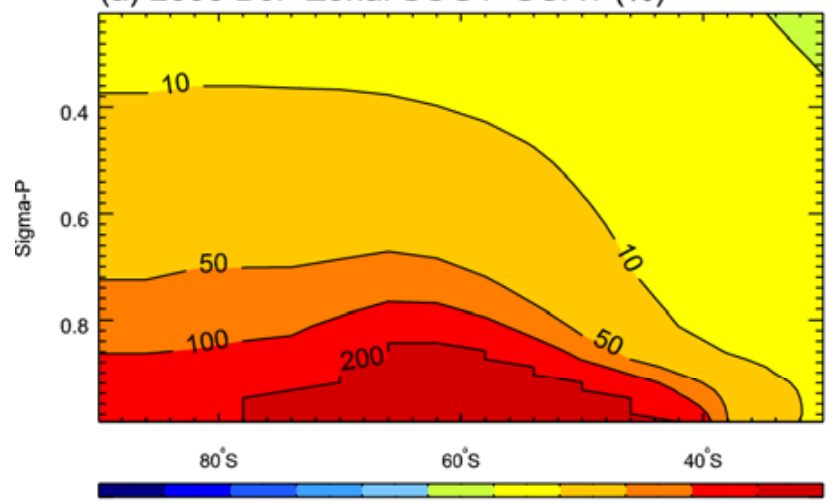

$\begin{array}{lllllllllll}-200 & -100 & -50 & -10 & -1 & 1 & 10 & 50 & 100 & 200 & \%\end{array}$

(c) 2006 DJF Zonal SOG4+SOA4 (\%)

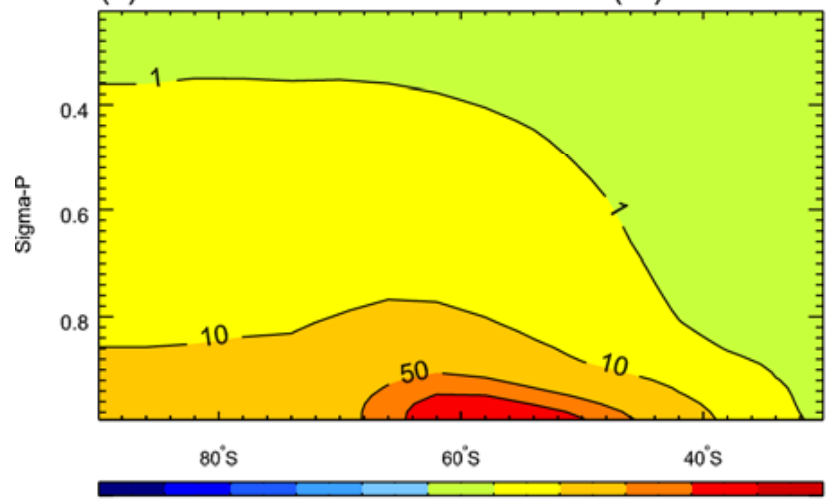

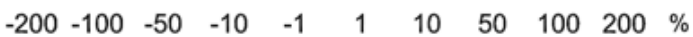

(b) 2006 DJF Zonal SOG1+SOA1 (ngC m $\left.{ }^{-3}\right)$

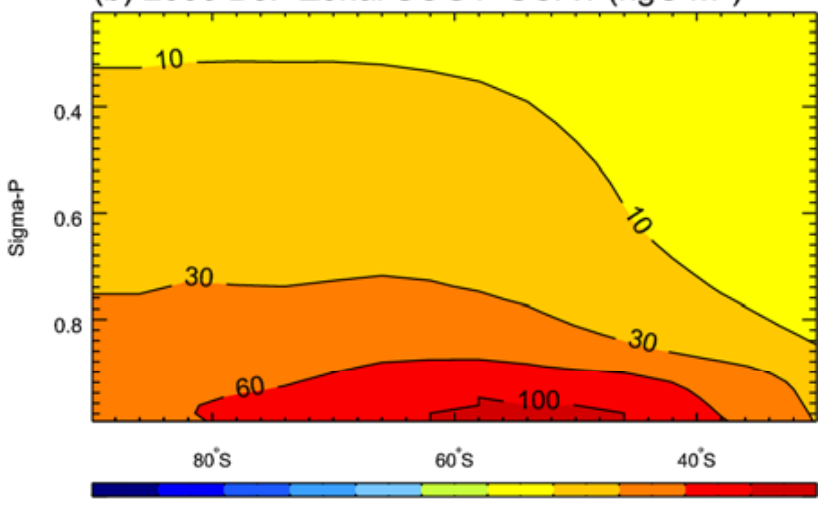

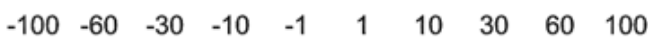

(d) 2006 DJF Zonal SOG4+SOA4 ( $\left.\mathrm{ngC} \mathrm{m}^{-3}\right)$

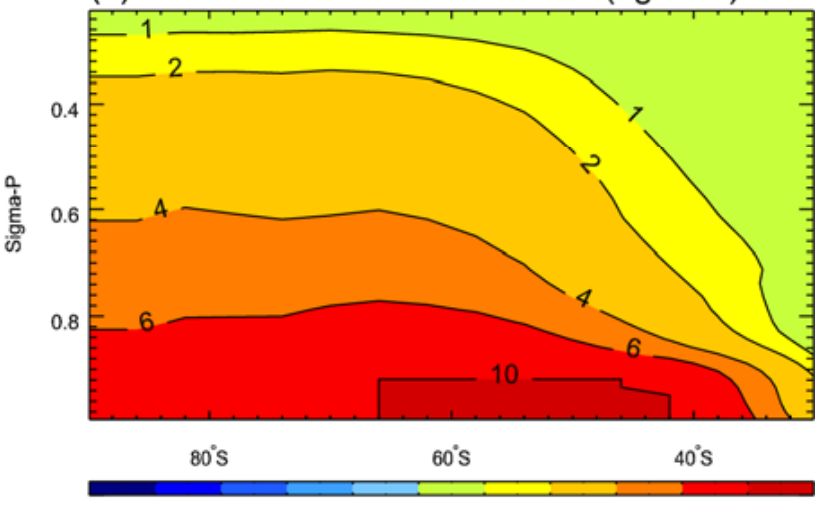

$\begin{array}{llllllllll}-10 & -6 & -4 & -2 & -1 & 1 & 2 & 4 & 6 & 10\end{array}$

Fig. 3. Zonally-averaged latitudinal and vertical distributions of relative (a), (c) and absolute (b), (d) differences in SOG1+SOA1 - (a), (b): the secondary organic gas and aerosol produced from $\alpha$-pinene and $\beta$-pinene group) and SOG4+SOA4 - (c), (d): the secondary organic gas and aerosol produced from isoprene group) between the MAE case (with oceanic $\alpha$-pinene and isoprene emissions) and the NOS case (without oceanic $\alpha$-pinene and isoprene emissions) during the summer season (DJF) in the Southern Hemisphere. The y-axis sigma-pressure is defined as the ratio of pressure to surface pressure.

gaseous (or secondary) OC emissions from ocean. OC mass emission estimations reported in some previous studies include primary OC particle emission. The sizes of these primary OC particles, which determine the particle number flux for a given mass flux, are unclear and remain to be investigated.

In this study, we seek to quantify the oceanic emissions of $\alpha$-pinene and isoprene using both "bottom-up" and "topdown" methods. An oceanic organics emission parameterization, which considers the influences of solar radiation, sea surface wind speed, and sea surface temperature, has been employed here to simulate the "top-down" oceanic emission of $\alpha$-pinene and isoprene. By constraining global chemistry model simulations with shipborne measurements of $\alpha$-pinene and isoprene concentrations over the Southern Ocean region, we derive a "top-down" global oceanic $\alpha$-pinene source of $29.5 \mathrm{TgC} \mathrm{yr}^{-1}$ and isoprene source of $11.6 \mathrm{TgC} \mathrm{yr}^{-1}$. In contrast, our calculated "bottom-up" global oceanic emissions of $\alpha$-pinene and isoprene are $0.013 \mathrm{TgC} \mathrm{yr}^{-1}$ and $0.32 \mathrm{TgC} \mathrm{yr}^{-1}$, respectively. The global oceanic $\alpha$-pinene source, quantified for the first time in this study, is significant (compared with the terrestrial source) based on "topdown" method, but is negligible based on "bottom-up" approach. The large offset in the derived oceanic organic emissions (especially for $\alpha$-pinene) is likely due to the incomplete understanding of the in-situ phytoplankton communities and their range of emission potentials as well as the uncertainties in the "top-down" approach. At this point, it is hard to tell which one is more close to the real values, and further research (especially measurements) is urgently needed to resolve the difference.

Our study indicates that the contribution of oceanic isoprene source, either based on "top-down" or "bottom-up" values, to the formation of oceanic secondary organics 
appears to be small. While the oceanic $\alpha$-pinene emission based on the "bottom-up" value has little effect on organic aerosol formation, our simulation shows that oceanic $\alpha$-pinene emission derived from the "top-down" approach can increase the zonally-averaged secondary organics concentration by up to $200 \%$ in the lower troposphere of the Southern Hemisphere $\left(40^{\circ} \mathrm{S}-90^{\circ} \mathrm{S}\right)$ during the austral summer season and thus may contribute to the seasonal variations of OC mass and the soluble fraction observed over coast and remote oceans.

Oceanic emissions of $\alpha$-pinene and isoprene highly depend on the biologically processes of phytoplankton in nature environment. The uncertainties in the numerical evaluation of global oceanic emissions of $\alpha$-pinene and isoprene presented here can be reduced by both further testing of phytoplankton emission potentials and by increasing the available observations of $\alpha$-pinene and isoprene abundances over biologically active and inactive oceans in different seasons. The uncertainties associated with the SeaWiFS chlorophyll-a concentration and mixing layer depth will impact the evaluation of total effective phytoplankton amount for $\alpha$-pinene and isoprene productivity. The dominant phytoplankton species suggested by PHYSAT model maybe different from the dominant emission effective species for $\alpha$-pinene and isoprene productivity, and it will impact the evaluation of global oceanic emissions of $\alpha$-pinene and isoprene via the "bottomup" approach. By using the "top-down" approach, the uncertainties associated with phytoplankton emission potentials maybe partially compensated by the prefactors. However, more available observations of $\alpha$-pinene and isoprene abundances over biologically active and inactive oceans in different seasons are required to improve the representative of remote marine $\alpha$-pinene and isoprene abundances on a larger scale. In addition, the higher $p$-ocimene emission rate measured in the monoculture experiments but the lower $p$ ocimene concentrations detected in the South Atlantic marine boundary layer (compared to $\alpha$-pinene) could indicate a high diversity of emission patterns over these regions.

Acknowledgements. This study is supported by NASA under grant NNX08AK48G. The GEOS-Chem model is managed by the Atmospheric Chemistry Modeling Group at Harvard University with support from the NASA Atmospheric Chemistry Modeling and Analysis Program. The authors thank Mr Alvain for providing the PHYSAT database of dominant phytoplankton classes.

Edited by: T. Karl

\section{References}

Alvain, S., Moulin, C., Dandonneau, Y., et al.: Seasonal distribution and succession of dominant phytoplankton groups in the global ocean: A satellite view, Global Biogeochem. Cy., 22, GB3001, doi:10.1029/2007GB003154, 2008.

Arnold, S. R., Spracklen, D. V., Williams, J., Yassaa, N., Sciare, J., Bonsang, B., Gros, V., Peeken, I., Lewis, A. C., Alvain, S., and Moulin, C.: Evaluation of the global oceanic isoprene source and its impacts on marine organic carbon aerosol, Atmos. Chem. Phys., 9, 1253-1262, 2009, http://www.atmos-chem-phys.net/9/1253/2009/.

Broadgate, W., Liss, P., and Penkett, S.: Seasonal emissions of isoprene and other reactive hydrocarbon gases from the ocean, Geophys. Res. Lett., 24, 2675-2678, doi:10.1029/97GL02736, 1997.

Ceburnis, D., Dowd, C. D. O., Jennings, G. S., et al.: Marine aerosol chemistry gradients: Elucidating primary and secondary processes and fluxes, Geophys. Res. Lett., 35, 1-5, doi:10.1029/2008GL033462, 2008.

Chung, S. H. and Seinfeld, J. H.: Global distribution and climate forcing of carbonaceous aerosols, J. Geophys. Res., 107, 4407, doi:10.1029/2001JD001397, 2002.

de Boyer Montégut, C., Madec, G., Fischer, A. S., et al.: Mixed layer depth over the global ocean: An examination of profile data and a profile-based climatology, J. Geophys. Res., 109, C12003, doi:10.1029/2004JC002378, 2004.

Gabric, A. J., Shephard, J. M., Knight, J. M., et al.: Correlations between the satellite-derived seasonal cycles of phytoplankton biomass and aerosol optical depth in the southern ocean: Evidence for the influence of sea ice, Global Biogeochem. Cy., 19, 1-10, doi:10.1029/2005GB002546, 2005.

Gantt, B., Meskhidze, N., and Kamykowski, D.: A new physicallybased quantification of marine isoprene and primary organic aerosol emissions, Atmos. Chem. Phys., 9, 4915-4927, 2009, http://www.atmos-chem-phys.net/9/4915/2009/.

Guenther, A., Baugh, W., Davis, K., et al.: Isoprene fluxes measured by enclosure, relaxed eddy accumulation, surface layer gradient, mixed layer gradient, and mixed layer mass balance techniques, J. Geophys. Res., 101(D13), 18555-18567, 1996.

Heald, C. L., Jacob, D. J., Park, R. J., et al.: A large organic aerosol source in the free troposphere missing from current models, Geophys. Res. Lett., 32, 1-4, doi:10.1029/2005GL023831, 2005.

Heald, C. L., Jacob, D. J., Park, R. J., et al.: Transpacific transport of asian anthropogenic aerosols and its impact on surface air quality in the united states, J. Geophys. Res., 111, 1-13, doi:10.1029/2005JD006847, 2006.

Kaufman, Y. J., Tanre, D., and Boucher, O.: A satellite view of aerosols in the climate system, Nature, 419, 215-223, 2002.

Lee, A., Goldstein, A. H., Kroll, J. H., et al.: Gas-phase products and secondary aerosol yields from the photooxidation of 16 different terpenes, J. Geophys. Res., 111, 1-25, doi:10.1029/2006JD007050, 2006.

Liao, H., Henze, D. K., Seinfeld, J. H., et al.: Biogenic secondary organic aerosol over the united states: Comparison of climatological simulations with observations, J. Geophys. Res., 112, D06201, doi:10.1029/2006JD007813, 2007.

Mayewski, P. A., Meredith, M. P., Summerhayes, C. P., et al.: State of the antarctic and southern ocean climate system, Rev. Geophys., 47, 1-38, doi:10.1029/2007RG000231, 2009.

Meskhidze, N. and Nenes, A.: Phytoplankton and cloudiness in the southern ocean, Science, 314, 1419-1423, doi:10.1126/science.1131779, 2006.

Murphy, D. M., Anderson, J. R., Quinn, P. K., et al.: Influence of sea-salt on aerosol radiative properties in the southern ocean marine boundary layer, Nature, 392, 62-65, 1998.

Nightingale, P., Liss, P., and Schlosser, P.: Measurements of air-sea gas transfer during an open ocean algal bloom, Geophys. Res. 
Lett., 27, 2117-2120, doi:10.1029/2000GL011541, 2000.

O’Dowd, C. D., Langmann, B., Varghese, S., et al.: A combined organic-inorganic sea-spray source function, Geophys. Res. Lett., 35, 1-5, doi:10.1029/2007GL030331, 2008.

Palmer, P. I. and Shaw, S. L.: Quantifying global marine isoprene fluxes using modis chlorophyll observations, Geophys. Res. Lett., 32, 1-5, doi:10.1029/2005GL022592, 2005.

Roelofs, G. J.: A GCM study of organic matter in marine aerosol and its potential contribution to cloud drop activation, Atmos. Chem. Phys., 8, 709-719, 2008,

http://www.atmos-chem-phys.net/8/709/2008/.

Spracklen, D. V., Arnold, S. R., Sciare, J., et al.: Globally significant oceanic source of organic carbon aerosol, Geophys. Res. Lett., 35, 1-5, doi:10.1029/2008GL033359, 2008.

Wanninkhof, R.: Relationship between wind speed and gas exchange over the ocean, J. Geophys. Res., 97, 7373-7382, doi:10.1029/92JC00188, 1992.
Yassaa, N., Peeken, I., Zöllner, E., et al.: Evidence for marine production of monoterpenes, Environ. Chem., 5, 391-401, doi:10.1071/EN08047, 2008.

Yokouchi, Y., Li, H.-J., Machida, T., Aoki, S., and Akimoto, H.: Isoprene in the marine boundary layer (Southeast Asian Sea, eastern Indian Ocean, and Southern Ocean): Comparison with dimethyl sulfide and bromoform, J. Geophys. Res., 104, 80678076, doi:10.1029/1998JD100013, 1999.

Yu, F. and Luo, G.: Simulation of particle size distribution with a global aerosol model: contribution of nucleation to aerosol and CCN number concentrations, Atmos. Chem. Phys., 9, 76917710, 2009, http://www.atmos-chem-phys.net/9/7691/2009/. 